\title{
The Course of Law: State Intervention in Southern Lynch Mob Violence 1882-1930
}

\author{
Kinga Makovi, Ryan Hagen, Peter Bearman
}

Columbia University

Abstract: Collective violence when framed by its perpetrators as "citizen" justice is inherently a challenge to state legitimacy. To properly account for such violence, it is necessary to consider an opportunity structure incorporating the actions of both vigilantes and agents of the state. The motivation and lethality of lynch mobs in the South cannot be understood without considering how the state reacted to the legitimacy challenges posed by lynching. We trace the shifting orientation of state agents to lynching attempts between the end of Reconstruction and the start of the Great Depression. Analyzing an inventory of more than 1,000 averted and completed lynching events in three Southern states, we model geographic and temporal patterns in the determinants of mob formation, state intervention, and intervention success. Opponents of lynching often pled with mobs to "let the law take its course." This article examines the course followed by the law itself, as state actors moved between encouraging, accommodating, and in many instances averting mob violence.

Keywords: lynching; politics; violence; collective action

Citation: Makovi, Kinga, Ryan Hagen and Peter Bearman. 2016. "The Course of Law: State Intervention in Southern Lynch Mob Violence 1882-1930." Sociological Science 3: 860-888.

Received: June 23, 2016

Accepted: July 15, 2016

Published: September 26, 2016

Editor(s): Jesper Sørensen, Sarah Soule

DOI: 10.15195/v3.a37

Copyright: (C) 2016 The Author(s). This open-access article has been published under a $\mathrm{Cre}$ ative Commons Attribution License, which allows unrestricted use, distribution and reproduction, in any form, as long as the original author and source have been credited. (C) (i)
TWO months after taking office as governor of Mississippi in 1904, James Kimble Vardaman chartered a special train to speed him from the state capital at Jackson to Batesville, the seat of Panola County in the state's rural northwest corner. He had telegraphed for troops from the state militia to meet him there. Vardaman meant to persuade a gathering lynch mob to spare the life of Albert Baldwin, who had recently been arrested on charges of murdering a railway engineer at Tutwiler, some 40 miles from Batesville. The militia was insurance against the failure of that appeal. Baldwin was black, the engineer white. The lynch mob was reportedly organizing at Tutwiler to storm the Batesville jail, remove Baldwin, and burn him at the stake. It was unclear who would reach the jail first: the governor and militia, or the mob. Vardaman, the son of a Confederate war veteran, was an outspoken white supremacist. Prior to taking office he had been a strident advocate of lynching. As governor, however, he directed state intervention in lynchings on at least nine different occasions (Holmes 1970:134). Vardaman had foreshadowed this change of heart publicly at a gubernatorial debate during the 1903 campaign. Discussing a recent lynching at Greenville, Mississippi, he told the audience:

Thank God the people there, as soon as they caught the negro, broke his neck. Now, it is said that Major Vardaman is teaching mob law. Let me say that if I was a Sheriff, and a mob came to the jail, I would run it off. If I was Governor, and the Sheriff called for troops, I would send the troops. But if I was neither Sheriff nor Governor, I would lead the crowd that would take him out and hang him. (New Orleans Daily Picayune July 23, 1903) 
It was seven months after this pronouncement that Governor Vardaman embarked on his trip to Batesville. As it happened, Vardaman and the militia reached Batesville first, took custody of Albert Baldwin, and returned with him by train to Jackson. Baldwin was tried, found guilty of murder, and sentenced to death by hanging in April of 1904 (Atlanta Constitution Feb 28, 1904; St Louis Republic Feb 28, 1904; New York Times Feb 29, 1904; Moberly Daily Monitor Mar 1, 1904; Atlanta Constitution Apr 7, 1904). It was unusual for a sitting governor to personally intervene in lynch mob violence. But agents of law enforcement and in some instances private citizens regularly confronted mobs in the Southern United States in the period during which the lynching of African Americans by white mobs was endemic in the region (1880-1930). Such interventions were often successful-they thwarted approximately one in every three lynching attempts (Hagen, Makovi, and Bearman 2013; Beck, Tolnay, and Bailey 2016).

Previous research has attempted to explain the temporal and spatial pattern of lynching in the South with respect to a wide array of political and economic factors (Beck, Massey, and Tolnay 1989; Olzak 1990; Beck and Tolnay 1990; Tolnay and Beck 1995a; Tolnay and Beck 1995b; Tolnay, Deane, and Beck 1996; Stovel 2001; Bailey et al. 2011; Franzosi, De Fazio, and Vicari 2012; Smångs 2016). This has been a very distinguished literature. Yet, it has been haunted by a strange mismatch between the theory that motivates the selection of independent variables-factors seen as driving white mobs to form for the purpose of lynching black individuals-and the dependent variable, lynching counts by space and time. The mismatch is rooted in design choices that have almost uniformly excluded from the analysis the large share of lynching attempts that failed because of interventions like Vardaman's (Raper 1933; Griffin 1993; Griffin, Clark, and Sandberg 1997a; Brundage 1993; Hagen et al. 2013; Beck 2015; Beck et al. 2016). The design mismatch gives rise to a classical problem in collective action research-developed most explicitly by Granovetter (1978) - which is that the inferences one can make from the study of successful instances of collective action-riots, strikes, and in the present case, lynchingare extremely limited unless two completely unlikely assumptions hold. In the case of lynching, these assumptions are either that the mobs that formed with the intention to lynch were uniformly lethal (we know this is not true: one in three were stymied) or that lynch mob lethality was random with respect to the social, political, and economic context in which it occurred (deeply improbable in any event, but especially because intervention almost always came from state agents, who would have been sensitive to how these contexts shaped the opportunities and constraints on their action). It is easy enough to show that these assumptions are wrong. More difficult-and the task undertaken in this article-is demonstrating that accounting for the geographic and temporal patterning of lynching requires identifying and understanding the contingent phases that constitute the act of lynching.

Through careful analysis of more than a thousand mob formation events in three Southern states, we identify three distinct but overlapping phases that produce the lynching rate. The first is the one that generates mobs. The second is the moment of possible intervention, conditional on a mob forming with the intent to lynch. The third is the interaction between the mob and intervening actors, conditional on an intervention attempt, the outcome of which determines whether the mob formation 
event ends in a lynching or an averted lynching. It follows that disentangling the common and unique mechanisms at play in each phase of lynching is the first task undertaken in this article. The second task is showing why this matters for our understanding of lynching in the Deep South. In so doing, we address an enduring puzzle-why did lynching as a repertoire of collective action decline so rapidly in the first decades of the twentieth century? We show that the answer is inaccessible if one does not consider the dynamics of intervention and intervention success.

\section{The Relevant Political Historical Background}

As even the most casual readers recognize, the context in which lynching occurred was enormously complex. But one historical fact is worth stressing at the outset: as the last vestiges of the Reconstruction-era power structure were being swept away and the Jim Crow regime rose in its place, state intervention in lynch mob activity increased in frequency and success while, following the legal disenfranchisement of African Americans, lynch mob formation gradually decreased. Ironically, despite many previous contributions identifying the crucial role of political context in driving mob formation (Olzak 1990; Soule 1992), the extant literature on lynching focuses almost exclusively on a subset of mob events—-those that were lethal —and this focus has shaped the literature such that the prevailing wisdom is that the political context is of little importance (Tolnay and Beck 1995a) ${ }^{1}$.

In other work, we noted that one condition for accepting this idea is an assumption that the South is uniquely different from everywhere else in the world, where political power struggles are the key factor in shaping ethnic and racial violence. While we will not here attempt to bury the theory of Southern exceptionalism, we simply point out that if political context shapes intervention and intervention success, then it would be very difficult to see those effects if, by design, one selected as their dependent variable on lynching success as an outcome. And yet, the historical record is clear. Across the South a revanchist political class that had campaigned on eliminating the "threat of black rule," and as its power was restored and became congealed into the institutions of the state and thus "legitimized," it moved to subdue the wave of extralegal violence it had previously encouraged-and not in small part used-to seize power. This fact helps make sense of the puzzle introduced at the outset of this article-why a vulgar white supremacist would advocate lynch mob violence as a private citizen, only to undertake extraordinary measures to thwart lynch mobs as governor. The Vardaman case in turn provides insight into the central question: why in the final two decades of the nineteenth century did it become common for Southern whites to murder African American men and women under the pretext of vigilante justice, and why did the practice become rare again by 1930 ?

Between 1865 and 1876 the defeat of the Confederacy, the forcible end of slavery, and the revolution constituted by Reconstruction radically altered social relations in the region. Violent, racially directed resistance to Reconstruction was frequent, typically taking the form of massacres, assassinations, and arson, rather than lynching (Foner 1988). Lynching before and during Reconstruction was primarily understood as a ritual of rough frontier justice exercised in regions beyond the stable control of 
government, not defined primarily by the racial categories of its perpetrators and victims (Wilson 1980; Arellano 2012). It is only after the collapse of Reconstruction with the Compromise of 1877 and the subsequent counterrevolutionary "Redemption" of Southern state governments that lynching reliably took on the qualitative and quantitative signatures that became indelibly associated with the phenomenon.

The restoration of home rule in the South in the late 1870s returned the white Southern elite to power under the banner of the Democratic Party, but it did not formally undo the changes wrought by Reconstruction. Chief among these changes was the institution of "a new electorate and a new electoral system" that included "about a million African Americans, most of them recently released from bondage," an expansion of suffrage legally secured at the federal level by the Fourteenth and Fifteenth Amendments and also at the state level through state constitutions established as the vanquished rebel states were readmitted to the Union (Perman 2001:10). For at least the first decade after Redemption, intimidation and widespread election fraud by the white establishment controlled the African American vote. This was especially true in the counties of the "black belt," in which the population was majority or near-majority African American. It was in these counties, Kousser writes, that "the vestiges of the antebellum ideology and social structure - the unqualified belief in the innate inferiority or even inhumanness of the Negro, the contradictory impulses to violence and paternalism, the acceptance of the hegemony of a tiny white elite - retained their greatest strength after the [Civil] War among whites" (Kousser 1974:16).

Following the end of Reconstruction the campaign of violence against and intimidation of black voters in these counties and across the Southern United States produced Democratic victories in what would otherwise have been likely Republican districts. However, as many of its proponents recognized, this strategy risked not only undermining confidence in Southern political institutions but also risked triggering renewed federal intervention to enforce the guarantee of franchise rights to African Americans (Key 1949; Kousser 1974; Perman 2001). White elites understood that formally undoing the legally protected civil status equality of African Americans through the legislative process would not only complete the counterrevolutionary move against Reconstruction but "would reinforce the Southern political system's legitimacy in the eyes of both Northerners and Southerners" (Kousser 1974:262-263) ${ }^{2}$. This process, beginning in the mid 1880s and not fully accomplished until 1908, occurred in waves and at different times in different states across the former Confederacy, relying on state constitutional conventions, statehouse legislation, and popular referendums.

This reconfiguration of the polity structured racial violence. Lynching became more frequent as the drive to formal disenfranchisement intensified. In many instances lynching was not a method of direct political oppression but a parallel function of the disenfranchisement campaign itself. At the heart of that movement was an argument that African Americans must not be afforded the rights and protections of citizenship as coequals to whites. In such a climate, whites in support of disenfranchisement could feel more "justified" in committing violence against blacks because as a class they were considered undeserving of due process. Under such logic, lynching might not have been considered by its perpetrators extrale- 
gal violence but rather necessary justice carried out by citizens against menacing outsiders. This argument was supported by political elites who argued publicly, vehemently, and frequently that blacks should be deprived of franchise on the grounds that they were inferior, dangerous, and should at all costs be driven from the civil sphere. For the same reasons, white law enforcement was also much less likely to stop lynch mobs. Following disenfranchisement, as questions over the racial civil status hierarchy were formally resolved to the satisfaction of the white polity, agents of a state that had shown itself to be entirely sympathetic to notions of white civil supremacy moved to reassert their traditional monopoly on the use of lethal violence.

Others have also considered disenfranchisement as centrally related to the decline of lynching, but previous attempts to test the effect of disenfranchisement on lynching were frustrated by two problems. The first we have already identified: analysts only considered lethal lynching events. Therefore, through the research design, all of the instances in which mobs formed but were thwarted by state (and other) actors were missing. The second is that disenfranchisement was seen as operating within the political threat framework. Beck and Tolnay (1995a) argue, for example, from within the political threat framework that there is no evidence of a direct relationship between lynching and African American political participation. But this argument does not rule out political conflict as a factor in mob formation and lethality. Consistent, for example, with Gould's argument on the role of status ambiguity in inducing group violence (Gould 2003), the drive to disenfranchisement could be seen as encouraging lynch mob formation by inducing ambiguity over the relative civil status and protections of whites and blacks, creating opportunities for interracial disputes to be settled through ritual violence that explicitly subverted the civil status of blacks relative to that of whites. In this context, the lethality of white mobs can be seen as mediated through the willingness and ability of agents of the state to successfully thwart these rituals. The rate of mob formation can be seen as influenced by the efforts of white supremacist governments to decisively resolve status ambiguity in favor of whites through disenfranchisement. It is in these ways that the lynching epidemic might have been shaped by the stability and composition of the political power structure at the county and state level.

As noted earlier, Granovetter (1978) showed why it is not possible to infer the motivations (and strengths of such motivations) of collective actors engaging in some collective action if one selects only on instances of success, as the determinants of success could as easily reflect intensity of motive as a favorable (stochastic) distribution of thresholds for action. Likewise, actors' beliefs about the potential costs of collective action could easily shape their participation, enhancing it when costs were perceived to be low relative to benefits and suppressing action when costs relative to benefits were perceived to be high. Consequently, the social, economic, and political drivers of lynch mob formation may or may not predict lynch mob lethality. Against this background, to understand the temporal and spatial pattern of lynching it necessarily follows that we need to understand the drivers of mob formation, the determinants of intervention, and the drivers of intervention success. As it turns out, each phase in the unfolding of a lethal lynch mob formation was shaped by different, albeit sometimes overlapping processes. The balance of this 
article is directed towards identifying the common and unique factors that shape the likelihood of each of these three moments in the unfolding of white on black violence in the South, focusing on three states (Mississippi, Georgia, and North Carolina) over the period from 1882 to 1930.

\section{Mob Formation Events and Interventions}

As indicated earlier, previous sociological work on lynching-aside from some case studies of averted lynching events and the most recent work by Beck and coauthors (2016) - has always selected on the outcome variable, thereby missing all of the instances in which mobs formed with the intent to lynch but were thwarted by successful intervention. Selecting on lethal outcomes means that, for our case, one in three cases are missing. Missing data is a problem when it is not random. Because mob lethality reflects the dynamics of mob formation and intervention rather than attitude intensity (all mobs, whether averted or lethal, were attitudinally motivated - that is, they had reasons to form), our explanatory models are significantly weakened. In the case of lynching, dropping averted lynching events has led social scientists to the odd consensus that economic rather than social and political factors were the primary drivers of lynching (Hagen et al. 2013), even though economic factors have been shown to be of limited explanatory power in most other instances of collective ethnic and racial violence (Snyder and Tilly 1972; Krueger and Pischke 1997; Green, Glaser, and Rich 1998; Green, McFalls, and Smith 2001; Eitle, D'Allessio, and Stolzenberg 2002).

Selecting on the outcome does not simply lead to a significant undercount of mob formation events but will also likely lead to biased estimates and the underestimation of the effect of the political context. It also incorrectly shapes our understanding of the kinds of events that were alleged to motivate lynching. Even in the Deep South, mobs always "justified" their intent to lynch on the basis of an alleged crime or racial transgression. A canonical finding in the lynching literature is that lynching was very common for social, rather than criminal, transgressions. It was, but selection on the outcome leads to an overestimation of such justifications for the simple reason that when lynch mobs formed to pursue men alleged to have committed capital crimes (rape or murder), law enforcement agent-charged with investigating crimes and upholding the law-were more likely to be in a position to intervene and potentially stop lynch mobs. One-third of those interventions were successful, and as a consequence, the alleged crimes that motivated the mob in those cases were not included in the lynching inventory, leading us to over estimate the proportion of lynching events legitimized by reference to non-capital crimes.

Despite these severe selection issues, there is much to build on from the prior literature. Our analysis examines the factors that have been most strongly associated with lynching. Among many factors, key is the relative size of black population, and dependence on cotton production (Beck et al. 1989; Olzak 1990; Beck and Tolnay 1990; Tolnay and Beck 1995a; Tolnay and Beck 1995b; Tolnay et al. 1996; Hagen et al. 2013; Smångs 2016; Beck et al. 2016). The central difference between older studies and our analyses neither arises from selecting new variables (although we do identify some) nor adding averted lynching to the inventory of mob formation events 
(although this is an important step). Rather, the key difference is that throughout this article we identify and focus our analysis on three separate, critical phases in the creation of a lynching event. We believe that this process can contribute to not only our understanding of lynching in this historical moment but of collective violence and social mobilization more generally. Consequently, we consider the drivers of mob formation, intervention in mob activity, and intervention success separately. This focus enables us to understand demographic, infrastructural, political, economic, and other factors that make a difference in shaping outcomes in each phase. The present article complements recent scholarship by Beck and coauthors (2016). Their work differs from ours in several crucial ways. First, while their geographic scope is wider, their temporal scope is narrower. They limit their analysis to the first three decades of the lynching era, excluding twenty years of mob formation events, but include data from all the states of the former Confederacy. Second, they exclude from the analysis any distinctions in the racial composition of mob victims and mob participants, an unusual choice given that racial tension is the animating core of the lynching phenomenon. Finally, their work considers intervention likelihood only, overlooking the dynamics in the lynching process as it unfolds, which is our central focus. The key finding of this most recent work by Beck et al. is that the likelihood of state intervention rose with the strength of the manufacturing sector and fell when Deep South qualities were more pronounced at the county-level, using a county-decade analysis framework. Beck and coauthors interpret these results as a manifestation of a drive to establish a "New South" by doing away with backward practices, such as lynching, which might discourage capital investment. Our work complements this line of scholarship but disentangles interventions which are lumped together by Beck et al. and decomposes the lynching process into the three key moments in order to identify which parts of that process were influenced by which factors.

\section{Geographic Sample}

Our data on mob formation is gathered from three Southern states: Mississippi, Georgia, and North Carolina. Mississippi and Georgia are chosen because they are representative of the Deep South and experienced the largest and second-largest number of lynching events, respectively, in the period under consideration. North Carolina is chosen as a representative of the Border South and because it experienced the fewest lynching events of any Southern state. Furthermore, North Carolina contains within it all of the different patterns of landholding and geography present across the states of the former Confederacy. The disenfranchisement movement advanced at different paces in each of these three states, and each state displayed differing levels of economic development and state strength in the period, allowing for a rich analysis that we believe is largely representative of the phenomena under consideration across the South.

\section{Establishing Mob Formation Counts}

The first problem is to establish mob counts (for mobs formed with the intent to lynch), and then to parse out from those mobs the events that experienced interven- 
tions (successful or not). To achieve this we rely on contemporary metropolitan and local news outlets available digitally. Because we utilize a self-collected database of lynching and averted lynching events introduced in a previous article, our description here is truncated. In brief, articles that fit our definition of averted or completed lynching are all event narratives, in which a person (or persons) was (were) accused of a crime or violation of racial norms, then were either pursued or threatened by a mob, which in turn either proceeded to lynch or was thwarted through an intervention of some $\mathrm{kind}^{3}$. From these accounts we have systematic information on place, time (to the nearest day), race and usually sex of the victim(s), the justification given for the mob's action, and the racial makeup of the mob ${ }^{4}$. In cases when mobs proceeded to lynch their victim, most narratives also reported the method of execution employed by the mob. When intervention occurred, we know whether it was successful or not, what form it took, and who-sheriffs, militias, state officials, or citizens-was or were involved.

The use of newspaper data-especially restricting ourselves to searchable digital archives-gives rise to concern over coverage bias. To test for coverage bias arising from the sources we selected, we compared our inventory of completed lynching events with the Beck-Tolnay inventory that is publicly available. On average, our search strategy produces roughly 90 percent of the cases in the Beck-Tolnay inventory, the race of the victim(s) and composition of mobs was the same in 98 percent of matched cases, and crime accusation against lynch victims coincided in 90 percent of the matched cases. The Beck-Tolnay inventory, which has been carefully built over years by dedicated research groups, can be compiled relatively accurately with modern techniques of data collection thanks to the increasing availability of digitized historical media. Interestingly, from the newspaper searches we discovered a handful of lynching events (mostly with unnamed victims) that are not part of the Beck-Tolnay inventory.

Averted lynchings are defined as events in which (1) a mob of three or more individuals formed or was perceived as imminently likely to form, (2) an express purpose of illegally killing a person under the pretext of service to justice or tradition was present, and (3) a clearly legible and successful intervention was made with the intent of foreclosing the possibility of mob violence. In this article we consider both successful interventions and failed interventions. Throughout this article we refer to all completed and averted lynching events as "mob formation events." We use only cases in which blacks were targeted by a primarily white lynch mob.

For close to a century, scholars have considered the implications of averted lynching. Raper's landmark study of lynching devoted a late chapter to "foiled" lynching events (Raper 1933). More recently, Griffin was a pioneer in emphasizing interventions (Griffin 1993; Griffin et al. 1997a) to point out that perhaps as many as half of attempted lynching events were foiled. Brundage (1993) gives similar estimates. Ellis (1986) focuses on a single event to highlight its contingent nature on intervention dynamics, while Campney writes about the suppression of mob violence in Topeka, Kansas (2013). Most recently, Beck (2015) described a newly collected (but not yet publicly available) inventory of averted lynching events from 1877-1950. In that article Beck speculates that state intervention was motivated by a desire to "assert the state's right to monopolize and arbitrate the administration 
of justice and to deny legitimacy of the mob as an agent of social control" (Beck 2015:135). In subsequent work Beck and coauthors find evidence for this process (2016). One contribution of this article is to empirically dissect the phases of lynching and consider the key moments separately.

Across the South, when lynch mobs formed, agents of the state regularly took measures of varying seriousness to defend black men and women from them. Newspapers routinely reported on both successful and unsuccessful instances of these interventions. This article analyzes a systematic collection of that data, structured in a way that allows us to see interventions as a class of event shaped by political forces concerning citizenship and the legitimate use of violence.

\section{Forms of Intervention}

Through careful analysis of newspaper accounts, we can distinguish two distinct categories of intervention events: direct and indirect interventions. We elaborate on each of these using qualitative detail from the newspaper accounts themselves ${ }^{5}$.

\section{Direct Intervention}

Physical, armed encounters between mobs and agents of the state were rare, occurring in 22 percent of lynch mob formation events. These clashes occasionally took the form of spectacular firefights or at least were reported as such. For example, in the summer of 1901, a mob attacked the jail at Carrollton, Georgia, in an attempt to lynch Ike Williams, who had been found guilty of murder and sentenced to death. The jail was defended by the county sheriff, along with his brother-in-law and state senator W.D. Hamrick, who had happened by the jail prior to the attack. Shortly after the mob forced their way into the jail, gunfire erupted between the mob and the jail's defenders. The leader of the mob was reportedly struck and killed in the exchange. The mob retreated, and the sheriff telegraphed Georgia Governor Allen Candler for reinforcements. State militia arrived, dispatched by the governor, and quelled any further disturbance (The Atlanta June 8, 1901; Chicago Daily Tribune June $8,1901)$. The Carrollton case was unusual in the ferocity of the defense put up by law enforcement before the mob. More often armed encounters involved sheriffs drawing their weapons and forcing their way into a mob, or standing off at gunpoint mob members who were trying to break into jails where prisoners were kept. In an example where the defense of the jail failed, a mob stormed the jail at Charlotte, North Carolina to remove the alleged murderers Joseph Kiser and Thomas Johnson in May of 1898. The sheriff and several deputies were "overpowered and the crowd rushed up the stairs toward the cell of the two men," whereupon "the lock was broken, the door opened and the prisoners hauled forth." The men were taken some distance from the jail and hanged (Baltimore Sun May 30, 1898).

Direct intervention sometimes took the form of rhetorical, rather than physical, engagement. In these cases mostly state actors were able to prevent lynching by engaging with mobs and persuading them to disperse or to release their victims alive. Generally, this strategy took the form of pleas to "let the law take its course," reinforcing the legal-regulatory frame of lynch mob activity. The status or personal 
charisma of the defender was often reported to be the key to success, as in the case of John Strait, saved from a lynch mob by county sheriff Loyd Brooks in Athens, Georgia, in October of 1894. A mob had captured Strait, blamed him for a recent murder, and was preparing to lynch him when sheriff Brooks appeared. Brooks demanded Strait's release and, according to a press account, the mob quickly complied, since "there are very few requests by Loyd Brooks that are not quickly granted, not only on account of his personal bravery, but also because of his great popularity among the people of his county" (Atlanta Constitution Oct 11, 1894). Strait was carried to jail pending trial. Charismatic sheriffs did not always intervene. They also colluded with mobs and/or allowed them to proceed. The charisma of Books is only part of the story. The key element for us is that Brooks chose to intervene.

As with each of the strategies we describe, rhetorical engagement sometimes failed, giving way to physical violence. In one striking case from Mississippi, a sheriff was carrying Charley Lewis to trial for murder when the pair was confronted by a mob of men armed with rifles and shotguns on arrival at Bankston Ferry in December of 1897. The sheriff was joined by several "cool-headed men," including a state senator and Methodist preacher, "who pleaded eloquently for the negro's life." Ultimately, the mob lost patience with the proceedings, rushed the sheriff and his deputies, and captured Lewis, hanging him from a nearby tree. According to the press account, "his body was left hanging by the roadside. Lewis denied his guilt to the last" (Atlanta Constitution Dec 12, 1897).

\section{Indirect Intervention}

Lynching was a local affair, rooted in community dynamics. As such, averting lynching was often accomplished simply by removing mob targets from the community, usually to a jail across county lines-"spirited away for safekeeping" in the parlance of the contemporary press. These transfers were sometimes preemptive, taking place before mobs decisively formed. Transfer of a mob target was also common after more serious encounters between mobs and agents of the state. A typical case was that of John Nunnally, arrested in Monroe, Georgia, in 1885 on suspicion of rape. In the middle of an August night a mob of men on horseback arrived at the Monroe jail demanding the sheriff surrender Nunnally to them. But the mob's arrival had been anticipated, according to a contemporary press account: "the sheriff had heard of the intended visit and had carried the negro to Gainesville the evening before" (Atlanta Constitution Aug 12, 1885). The mob withdrew, foiled.

Such transfers posed their own risks, as they presented opportunities for mobs to seize their targets away from the relatively more secure confines of jails and courthouses. These risks were realized in the case of Duncan McPhatter, lynched in North Carolina in November of 1892. McPhatter had been charged with murdering a deputy sheriff who had tried to arrest him for attempting to cast a ballot in the closely contested 1892 election. The deputy sheriff was reportedly fatally shot when he went to arrest McPhatter at his home. McPhatter was taken to a nearby jail in Laurinburg, and then put on a train headed to Rockingham, about 40 miles away, for fear that he would be lynched if he remained. On departure, a large mob of 
men armed with rifles boarded the train, overpowered the officers aboard, and commandeered the locomotive. The mob ordered the train stopped near Laurel Hill, just outside Laurinburg, where McPhatter was dragged from the train and lynched (Atlanta Constitution Nov 19, 1892; Boston Globe Nov 19, 1892).

As direct confrontation of mobs was risky, indirect interventions sometimes involved actively avoiding mobs by eluding them during a chase or hiding prisoners from the mob. An account from North Carolina in 1921 tells of a lynch mob in automobiles that "raced with a passenger train for fifteen miles in an effort to overtake it at a stopping point and get possession of Alfred Bennett," who was aboard in police custody in connection with the murder of a merchant. The cars were unable to overtake the train, and ultimately Bennett was carried to the state prison in Raleigh (Kansas City Star Jan 19, 1921). In Dallas, Georgia, in 1916, a sheriff got word that a mob was en route to the jail to lynch Edward Dozier, charged with the murder of a policeman in the nearby town of Rome. Rather than risk an armed encounter, the sheriff "hurried [Dozier] from his cell and took him into the dense woods nearby. When the mob arrived and demanded entrance to the jail, the jailer . . . let them in and showed them the empty cell. Disappointed, they withdrew" (Atlanta Constitution Dec 9, 1916).

Occasionally the show of force was all that was necessary to signal to mobs that law enforcement was serious about preventing extralegal violence. This strategy included increased patrols of municipalities to discourage gatherings, increased posting of guards at local jails, the conspicuous arming of judges in courtrooms, or the deployment of armed militia. In Conyers, Georgia, in the autumn of 1884, Tom Marston was arrested under suspicion of arson and desecration of the local cemetery. A lynching was widely anticipated, but apparently prevented by the posting of armed guards around the jail, "ready to open fire upon the crowd if an attempt is made to force an entrance into the building" (Chicago Daily Tribune Sep 16, 1884). Similar precautions likely saved Nathan Montague from extralegal violence in Oxford, North Carolina, in January of 1911. Montague had been arrested and charged with murder, was given a six-hour trial and convicted after an eight-minute jury deliberation, and was sentenced to death by electrocution. The newspaper account reported that: "any other verdict would, it is said, have brought on a lynching." Montague had been brought to Oxford for trial by train under guard of two companies of state militia. The militia "carried a gatling [sic] gun on a flat car" for defense against anticipated mob violence (The Washington Post Jan 17, 1911).

\section{Coding Direct and Indirect Interventions}

All mob formation events that saw direct or indirect interventions were coded as such with the specific details of the intervention, regardless of the intervention's outcome. To summarize: direct interventions included physical engagement with mobs but also less combative actions like rhetorical persuasion-referred to in the press as "talking down the mob." These interventions are cases of confrontation, in which agents of the state or ordinary townsfolk set themselves in clear opposition to actors intent on extralegal killing, most of the time "risking" that their names would be published as part of journalistic accounts. Indirect interventions sought 
Table 1: Geographic distribution of mob formation events and interventions by category.

\begin{tabular}{lcccc}
\hline & All three states & Georgia & Mississippi & North Carolina \\
\hline Mob formation events & 1,277 & 673 & 435 & 169 \\
Interventions (\%) & $55 \%$ & $62 \%$ & $35 \%$ & $80 \%$ \\
Direct interventions (\%) & $22 \%$ & $24 \%$ & $15 \%$ & $28 \%$ \\
Indirect interventions (\%) & $44 \%$ & $49 \%$ & $27 \%$ & $67 \%$ \\
Successful interventions (\%) & $46 \%$ & $54 \%$ & $24 \%$ & $67 \%$ \\
Equivocal interventions (\%) & $17 \%$ & $14 \%$ & $24 \%$ & $12 \%$ \\
\hline
\end{tabular}

to defuse mob violence by changing the dynamics of the situation in such a way as to prevent or reduce the possibility of direct confrontation. These actions included removing a mob target from the community by sending him to a distant jail across county lines or hiding mob targets when their attackers came looking. Deterrence actions such as posting of extra guards or armed militia units are also part of this category.

The actors taking defensive measures against mobs that formed with the intent to lynch were usually county sheriffs, deputies, or other local officers. Private citizens also intervened, albeit infrequently, mostly by verbally addressing the mob and pleading for the life of the accused, arguing that law enforcement actors should take over. Occasionally judges took part. Governors often ordered the mobilization and dispatch of militia units to protect jails or disperse mobs, but in eight cases documented in our inventory, state executives intervened personally (as in the Vardaman case with which we opened this article), issuing public statements or making personal appeals to lynch mobs.

\section{The Demography of Mob Formation Events}

We describe the distribution of mob formation events, those that received direct and/or indirect interventions (some events received both direct and indirect interventions, some received only one of these, and some saw no interventions), and those that saw successful interventions in Table 1. Percentages should be read as the proportion of all instances of mob formation categorized as lynching or averted lynching events.

In Table 2, interventions are broken down by the most typical actions taken and by the actors who most typically intervened. When a specific intervention was invoked multiple times-for instance, when a person was moved multiple times to different jails-the prisoner transfer strategy is recorded only once in this tabulation. However, intervention events often included multiple strategies and multiple actors-for example, a verbal engagement followed by a distant move. In this example, the local pastor who talks the mob down and the sheriff who subsequently moves the mob target across county lines would be separately coded, and each included in the calculations of percentages for Table 2. Therefore, column percentages in Table 2 do not add up to 100 percent. To illustrate: A value of 24 percent in the cell for verbal engagement means that about one-fourth of the events 
Table 2: Distribution of events receiving interventions, with respect to strategies taken and actors involved.

\begin{tabular}{ll|ll}
\hline \multicolumn{2}{c}{ Actions Taken } & \multicolumn{2}{c}{ Actors } \\
\hline Direct interventions & & Nonlocal & $24 \%$ \\
Verbal engagement & $24 \%$ & Local law enforcement & $71 \%$ \\
Physical engagement & $19 \%$ & Local non-law enforcement & $13 \%$ \\
Indirect interventions & & & \\
Transfer to local jail & $10 \%$ & & \\
Deception and/or elusion & $12 \%$ & & \\
Show of force & $23 \%$ & & \\
Distant move & $53 \%$ & & \\
\hline
\end{tabular}

recorded in our dataset, regardless of the outcome for the mob target, included an episode in which state actors or local law enforcement tried to persuade the mob to stand down. Note that this number does not mean that this was the only intervention present in the case.

\section{The Drivers of Mob Formation, Intervention Likelihood, and Intervention Success}

The systematic analysis of mob formation and intervention dynamics requires that we capture motives and opportunities for lynching as well as motives and opportunities for intervention. Here we consider which factors are likely to be associated with each moment-that is, with mob formation, intervention likelihood, and intervention success separately. Our strategy is to build and expand on previous literature. In part, by doing so, we can see where traditional explanations work, and where they need to be augmented when considered under the integrated framework we adopt. Table 3 reports which factors are thought to play a role in each of the three separate moments under consideration, those that drive mob formation, intervention, and intervention success. For each variable we provide two pieces of information. A "+," ",-, or "=" sign indicates the expected direction for each variable when applicable, where " + " indicates a positive relationship, a "-" indicates a negative relationship, and an " $=$ " indicates unclear expectations, and "N/A" stands for "not applicable." Finally, $\checkmark$ indicates if a certain specification is used.

We discuss each model separately but first describe measurement and expectations for the five factors we believe are relevant for each of the separate moments. While present for each phase, these shared variables need not have consistently shared effects. For example, most analyses of the existing lynching inventory link lynching to racialized political and/or economic contestation. Because proportion black was positively related to contestation-up to a threshold typically observed to be around 0.6 (Blalock 1967; Reed 1972; Creech, Corzine, and Huff-Corzine 1989) - it should be positively related to mob formation (Blalock 1967). On the other hand, we anticipate an inverse relationship between proportion black and 
Table 3: Distribution of events receiving interventions, with respect to strategies taken and actors involved.

\begin{tabular}{lccc}
\hline Variable & Mob formation & Intervention & Intervention success \\
\hline$\%$ black & + & - & $=$ \\
\% black squared & - & $\mathrm{N} / \mathrm{A}$ & $\mathrm{N} / \mathrm{A}$ \\
Cotton dependency & + & - & - \\
Cotton price & - & + & + \\
Inflation & + & - & - \\
Railroad density & - & + & + \\
Railroad density squared & - & $\mathrm{N} / \mathrm{A}$ & $\mathrm{N} / \mathrm{A}$ \\
Opposition to the Democratic Party & - & + & + \\
Disenfranchisement & - & $\mathrm{N} / \mathrm{A}$ & + \\
\% slaves in 1860 & - & $\mathrm{N} / \mathrm{A}$ & $\mathrm{N} / \mathrm{A}$ \\
Average \# of slaves per owner & - & - & + \\
Noncapital crime & $\mathrm{N} / \mathrm{A}$ & $\mathrm{N} / \mathrm{A}$ & + \\
Involvement of nonlocal actors & $\mathrm{N} / \mathrm{A}$ & $\mathrm{N} / \mathrm{A}$ & + \\
Indirect intervention & N/A & $\mathrm{N} / \mathrm{A}$ & - \\
Direct intervention & N/A & $\checkmark$ & $\checkmark$ \\
State fixed effects & N/A & Logistic & Logistic \\
\hline Model type & Negative binomial & \\
& \# of events per county-year, & & \\
\hline
\end{tabular}

intervention, conditional on mob formation. Finally, intervention success should rise with percent black. In short, the same variable plays different roles at different moments. We capture the ratio of the black population to the total population on a $0-100$ scale, using data drawn from the decennial census. Linear interpolation is used in between measurements.

Three interrelated measures proxy the economic competition between blacks and whites used widely in the lynching literature: cotton dependency, cotton prices, and inflation. Cotton dependency is measured as the ratio of acres of cotton to acres of farmland on a 0-100 scale. This measure was constructed using the Agricultural Census $^{6}$. As before, linear interpolation is used in between measurements. We used inflation-corrected cotton prices ${ }^{7}$ and calculated inflation based on the GDP deflator. Cotton dependency has been shown to have a positive relationship to lynching and averted lynching events (Hagen et al. 2013; Beck et al. 2016). Likewise, a relationship has been demonstrated between cotton prices and the lynching rate (Tolnay and Beck 1990). In good times, exemplified by low inflation and high real cotton prices, lynching declines; in bad times, exemplified by high inflation and low real cotton prices, the lynching rate increases. Given solidarity between state actors and the elite white population, we expect the likelihood of intervention to decrease as cotton dependency increases and this relationship to be more pronounced in periods of economic hardship. For the same reasons, the likelihood of law enforcement intervention success should be negatively related to cotton dependency and cotton prices. 
As with economic relations, the political climate is implicated in shaping the likelihood of intervention and intervention success in different ways. Countylevel Republican strength has been found to decrease mob formation and increase the likelihood of averted lynching events (Hagen et al. 2013). Thus we expect that Democratic opposition should be negatively related to mob formation but positively related to the likelihood of intervention and intervention success. In order to measure the effect of the political climate and the solidification of the one-party South, we measure opposition to the Democratic Party. The variable was constructed by subtracting the Democratic vote share in percentages from 100, thereby getting a measure on the scale of $0-100$. For each county-year or event we used the results from the most recent presidential election ${ }^{8}$.

Clearly important for understanding lynching is the social and economic legacy of the plantation system. Cotton dependency is often thought to capture this legacy, but a more nuanced approach would be to directly consider the total number of slaves and the average size of slaveholdings from the 1860 census, by county. For both of these legacy measures, the higher the figure, the more frequently we should expect lynch mob formation and the less frequently we should see interventions and intervention success.

The successful establishment of disenfranchisement in a state should increase the likelihood and success of interventions. We operationalize disenfranchisement through a variable that is 0 up to the year in which disenfranchisement was enacted, and 1 in the year of enactment itself. In subsequent years the value of the variable increases by the natural logarithm of the difference between the current year and the year in which disenfranchisement was enacted-i.e., it is increasing but plateaus over time ${ }^{9}$. To establish the year of disenfranchisement enactment, we choose the year in which a common basket of restrictive voting laws were passed. This happened at different times in the three states we consider: in Mississippi in 1890 (the introduction of the poll tax, literacy test, understanding clause, and secret ballot); in North Carolina in 1900 (the introduction the poll tax, the literacy and property tests, and the grandfather clause); and in Georgia in 1908 (the introduction of the literacy and property tests and the understanding and grandfather clauses) (see Griffin et al. 1997b:14, Table 1).

\section{Structural Opportunities and Constraints}

For mobs to form they need a reason and the capacity to mobilize and carry through their lethal action. Likewise, intervention requires both motivation and capacity. The previous literature has focused extensively on motive; here we explicitly incorporate two elements of the opportunity structure that shaped mob formation and the response (or not) it engendered. The key capacity measures for this period are urbanization and the integration of communities into the larger political and economic arena of the state through the development of infrastructure. Each are tied to the dynamics of mob formation and state intervention in different ways.

To appropriately model these opportunities and constraints, we must reconsider the interpretation of some of factors that had previously been linked solely to the motivation of mobs. Specifically, county proportion black has generally been 
treated as a proxy for white desire to control and suppress blacks. At the same time, in this period, proportion black is negatively related to urbanization. We expect urbanization to increase the likelihood of interventions and intervention success because urban areas were easier to police and control. In this context, it is important to note that fortified state penitentiaries were found near or within cities, which made protecting mob targets easier. Urbanized areas also had more extensive public resources (railroads, roads, larger police forces, etc.) at their disposal. In addition to proportion black, we capture urbanization by county railroad density, defined for 1876, 1883, 1890, 1893, 1912, and 1921 as miles of railroad track within each county ${ }^{10}$, with linear interpolation between measurements.

A specific form of intervention-moving mob targets to distant prisons by train, which occurred in roughly one-third of intervention cases-were more likely in communities with access to a robust transportation infrastructure. Consequently, we expect that both interventions and their success will have been more likely where railroads were more readily at the disposal of law enforcement. Because telegraph lines were developed along railroads, railroad density also captures an important resource for law enforcement, specifically telecommunication, which influenced the speed of response to mob threats as indicated in the Vardaman account with which we began ${ }^{11}$.

$\mathrm{O}^{\prime}$ Connell finds that contemporary black-white inequality is associated with 1860 slave concentration-independent of current demographic and economic conditions - race disparities in wealth, and racial threat, captured by proportion black and its square term ( $\mathrm{O}^{\prime}$ Connell 2012:713). To incorporate the legacy of slavery we measure it with a combination of variables capturing different aspects of the pre-Civil War economy: the percentage of slaves of the free population on a $0-100$ scale and the average number of slaves per owner drawn from the 1860 census. These variables capture both the penetration of slavery, and the extent to which large plantations were typical.

We also consider the nature of the crimes that mobs claimed provoked their actions. The severity of an alleged crime would have influenced the likelihood of rapid response by law enforcement. Allegations of murder or rape (both capital crimes) would have drawn a swift response from local sheriffs, who would have quickly attempted to take suspects into custody in the regular discharge of their duty. Noncapital crimes, or crimes of deportment, would have been less likely to rouse law enforcement, giving mobs more time to act prior to the involvement of state agents. Thus, increasing severity of crime accusations that provoke mob formation should also increase the likelihood of state intervention. The effect of crime severity, however, is reversed when it comes to intervention success. Law enforcement would have had more trouble defending alleged rapists and murderers from highly motivated mobs and conversely would have had more success defending those accused of noncapital crimes. We measure the alleged crime with a dummy variable that takes 1 in cases in which the mob targeted its victim for a noncapital offense.

Lastly, both direct and indirect interventions are both measured with dummy variables, for which a 1 indicates direct and indirect interventions, respectively. Recall that these are not exclusive categories: a mob formation event could see none, 
either one, or both. The involvement of nonlocal actors is also measured with a dummy variable that takes 1 in the event that nonlocal actors were involved.

\section{Analysis Strategy}

As we demonstrated earlier, lynching events emerge from a three-phase process: mob formation, intervention, and intervention success. This framework can be specified as follows:

$$
\begin{gathered}
\text { Lynching } \operatorname{count}(/ \text { county-year })= \\
\text { mob count }(/ \text { county-year }) \cdot[p(\text { no intervention } \mid \text { mob formation }) \\
+p(\text { intervention } \mid \text { mob formation }) \cdot p(\text { unsuccessful intervention } \mid \text { intervention })],
\end{gathered}
$$

where $p($.$) is probability and p(. \mid$.$) is conditional probability. And,$

$$
\begin{gathered}
p \text { (unsuccessful intervention I intervention \& mob formation }) \\
=p(\text { unsuccessful intervention I intervention })
\end{gathered}
$$

by definition.

We present three sets of analysis, one for each phase of the process-for mob counts, for the probability of intervention, and for the probability of intervention success. The unit of analysis of these models differ. Because the mob formation data are seriously overdispersed, mob counts are modeled at the county-year level using a negative binomial model. The probability of intervention is calculated by classifying events of mob formation into two categories: those that saw interventions of any kind and those that did not. Finally, the probability of intervention success is calculated by classifying events of mob formation that saw interventions into two categories: those that saw successful interventions and those that saw failed interventions. For these analyses we place events in counties, given that counties were the basic unit by which law enforcement organized in the South during this period. Throughout these analyses we fix counties as they existed in 1880 to avoid attributing changes in both our dependent and independent variables to changing county boundaries over time. When yearly data are not available, we linear interpolate between observations unless otherwise specified. Model selection issues and robustness checks are presented in the online supplement.

\section{Results}

\section{The Drivers of Lynch Mob Formation}

What drives lynch mob formation? The results of our analysis are presented in Table 4. Higher levels of cotton dependency are associated with elevated mob frequency. Cotton prices and inflation have modest effects. This is by-and-large consistent with the hypothesis that status struggles, especially concentrated within the economic sphere, led to more frequent and violent conflicts between whites and blacks. Further evidence for this is the curvilinear and substantively important 
Table 4: The determinants of mob formation.

Variable

$\%$ black

$0.0471^{\dagger}$

$\%$ black squared

(0.0065)

$-0.0004^{\dagger}$

(0.0001)

Cotton dependency

$0.0130^{\dagger}$

$(0.0037)$

Cotton price

$-0.0030^{\dagger}$

$(0.0009)$

Inflation

$0.0263^{\dagger}$

(0.0069)

Railroad density

$0.2525^{\dagger}$

$(0.0629)$

Railroad density squared

$-0.0260^{*}$

(0.0106)

Opposition to the Democratic Party

$-0.0067^{\dagger}$

(0.0018)

Disenfranchisement

$-0.1128^{\dagger}$

$(0.0212)$

\% slaves in 1860

0.0090

(0.0088)

Average \# of slaves per owner

Constant

$+p<0.01 ; * p<0.05$.

Negative binomial model, units: 1880 county-years, standard error clustered on 1880 counties

association of percent black to mob counts, consistent with Blalock's power-threat hypothesis. These results hold both qualitatively and quantitatively in alternative specifications.

Democratic opposition has a negative association with mob counts. After disenfranchisement, the anti-Democratic vote collapses (Kousser 1974), inaugurating the one-party South. Disenfranchisement is associated with decreased frequency of mob formation because through disenfranchisement whites' power was secured. Finally, the development of infrastructure measured by the length of railroads has a curvilinear effect. None of these factors are as substantively significant as percent black and disenfranchisement.

\section{Modeling the Probability of Intervention}

In this second stage, we use a logistic regression to parse out the factors that drove interventions. We use state-level fixed effects as resources available at the state level; 
Table 5: The determinants of intervention.

Variable

$\%$ black

$-0.0142^{\dagger}$

$(0.0050)$

Cotton dependency

$(0.0075)$

Cotton price

$-0.0003$

(0.0018)

Inflation

$(0.0140)$

Railroad density

$0.3521^{+}$

Opposition to the Democratic Party

Disenfranchisement

Noncapital crime

Constant

$+p<0.01 ; * p<0.05$.

State fixed-effects are used.

i.e., militia personnel are unmeasured and likely to be correlated with both the error term and the independent variables, resulting in biased and inconsistent estimates. This specification assumes, confirmed by the historical record, that the differences between states are stable over time such that their trajectories on these unobserved factors remain parallel. As expected, interventions were less likely to occur as proportion black increased and less likely to occur under Democratic hegemony and after disenfranchisement. Importantly, interventions are much less likely when mobs targeted blacks for noncapital crimes. The development of infrastructure (railroads) increased the likelihood of intervention, as expected. Neither cotton dependency nor cotton prices have any statistically significant effect at all on intervention likelihood in any of the model specifications. In contrast, proportion black remains significant in driving intervention likelihood. Intervention likelihood decreases as the black population increases. These results are reported in Table 5 .

Figure 1 reports the predicted number of intervention events (dashed line with the gray area for the 95 percent confidence interval) compared to the observed number of interventions over time (solid black line) smoothed using three-year moving averages. Overall, substantive model fit is excellent, capturing the temporal dynamics of intervention quite well. In Figure 2 we show the same data, and the prediction if disenfranchisement had not happened: the dashed line represents the median of the number of interventions that would have occurred if disenfranchisement had not happened. As can be seen, without disenfranchisement we would 


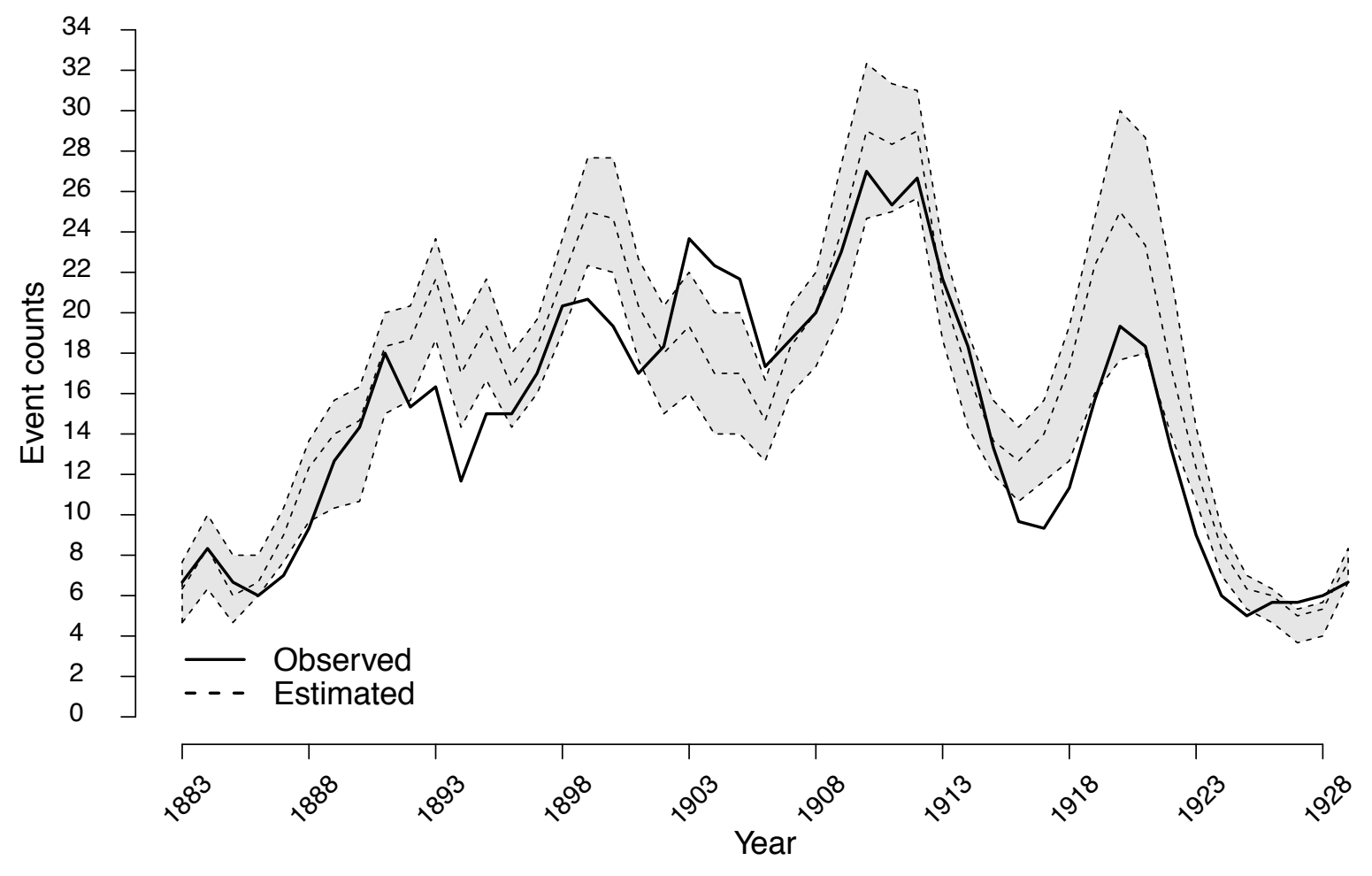

Figure 1: Predicted number of intervention events (dashed line with the $95 \%$ confidence intervals shown by the gray area) compared to the observed number of interventions (solid line) over time using three-year moving averages.

systematically underpredict the number of mob formation events that experienced interventions.

\section{Modeling the Probability of Intervention Success}

In the final stage, we employ the same framework as before: a logistic regression to parse out the factors that drove intervention success, conditional on intervention. The results underscore that success was primarily determined by the actions taken and the actors involved in intervention. The involvement of nonlocal actors was positively associated with intervention success. Interestingly, direct interventionsin which state actors physically confronted mobs-were negatively associated with intervention success . Indirect interventions have a substantively important, positive association with the likelihood of intervention success. Proportion black and democratic opposition have weak, nonsignificant effects in the anticipated directions. As with intervention likelihood, neither cotton dependency nor cotton 


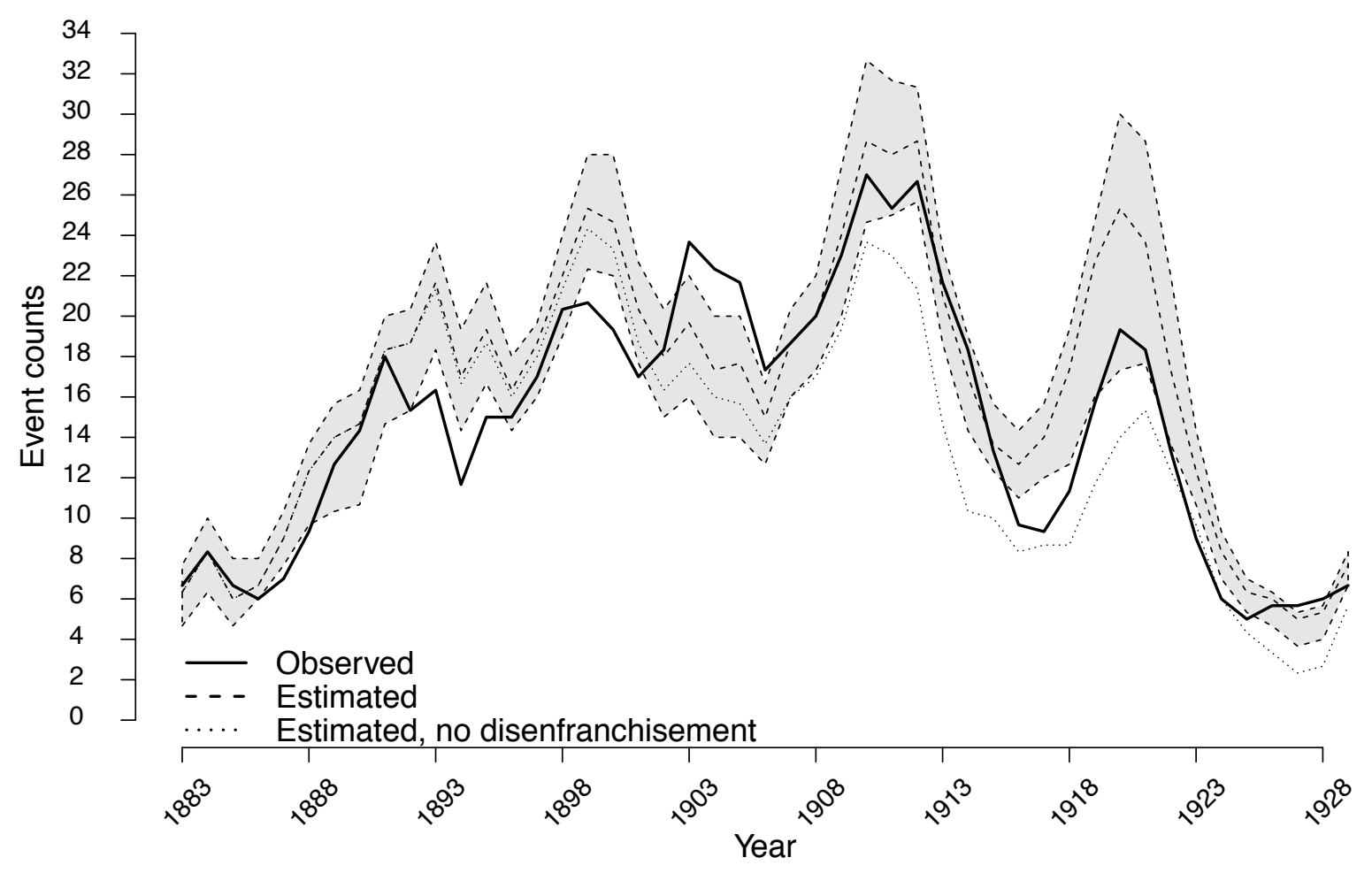

Figure 2: Predicted number of intervention events (dashed line with the $95 \%$ confidence intervals shown by the gray area) compared to the observed number of interventions (solid line) and the predicted number of interventions without disenfranchisement (dotted line) over time using three-year moving averages.

prices have a significant relationship to intervention success. These results are detailed in Table 6.

At first glance it seems surprising that disenfranchisement does not have a direct effect of intervention success. However, disenfranchisement strongly shapes who intervenes and how intervention occurs. This can be seen by shifting our focus to state-specific disenfranchisement histories. In Table 7, we compare each state's pre- and post-disenfranchisement intervention pattern. In Mississippi and North Carolina, both nonlocal and indirect interventions increase dramatically after disenfranchisement. Figure 3 reports the number of predicted and observed successful interventions over time. For both Mississippi and North Carolina, the substantive model fit is excellent, capturing the temporal dynamics of intervention success quite well. The pattern is, as anticipated, less clear in Georgia, where disenfranchisement as a process was temporally uneven and its effects messier as a consequence. 
Table 6: The determinants of intervention success.

Variable

$\%$ black

$-0.0085$

Cotton dependency

$-0.0131$

(0.0106)

Cotton price

$-0.0005$

$(0.0030)$

Inflation

$-0.0074$

(0.0236)

Railroad density

(0.1079)

Opposition to the Democratic Party

Disenfranchisement

Noncapital crime

$0.7375^{*}$

Involvement of nonlocal actors

Indirect intervention

$0.6593^{*}$

(0.2894)

Direct intervention

Constant

$+p<0.01 ; * p<0.05$.

State fixed-effects are used.

\section{Discussion}

Lynch mobs framed their actions as retribution for criminal transgressions. This framing set mobs in direct conflict with the authority of law enforcement locally and the legitimacy of the state more generally. In the South, in the 50 years following the defeat of Reconstruction, state agents failed to stop two out of every three lynching attempts. The remaining third they averted. The bulk of these interventions took place in the years following the disenfranchisement of African Americans and the consolidation of the white supremacist Jim Crow regime. Mobs were most lethal, on the other hand, and least likely to be opposed by law enforcement in the years leading up to disenfranchisement, a period in which Democratic candidates waged virulently racist campaigns stoking white fears of black political rights while promising to degrade the civil status of blacks to the fullest extent possible.

The tragedy of lynching unfolded in the context of a broad, racialized struggle over the legitimacy of the state in the eyes of white Southerners. To whom did the 


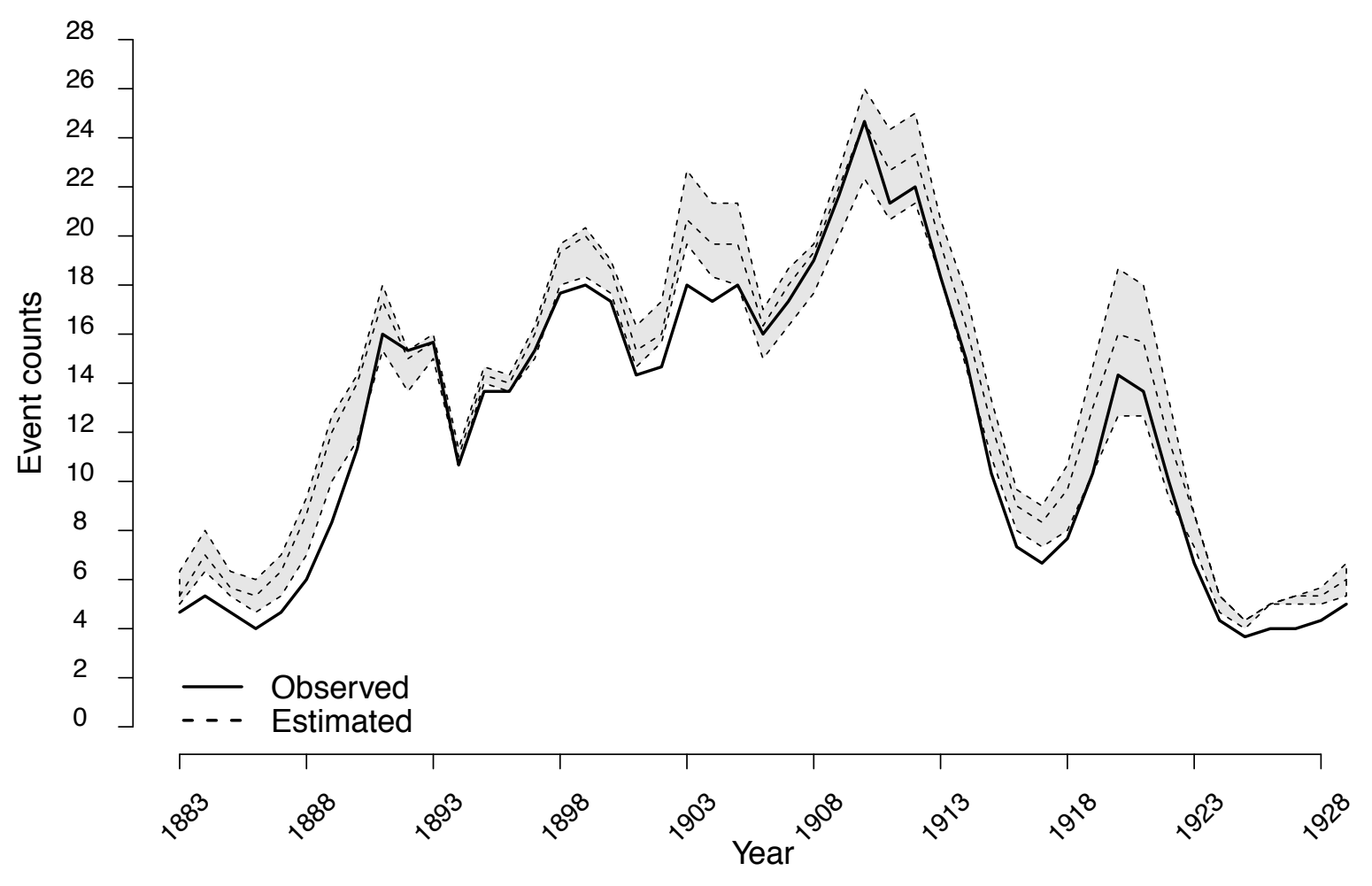

Figure 3: Predicted number of successful intervention events (dashed line with the $95 \%$ confidence intervals shown by the gray area) compared to the observed number of successful interventions (solid line) over time using three-year moving averages.

state belong? Whose interests did it serve? Would the power structure imposed by Northern radical reconstruction be finally dismantled, and the black population pushed into a state of "second slavery" (Du Bois 1994 [1903]), restoring white supremacy? This is the struggle gubernatorial candidate James Vardaman joined as he told voters he would lead a lynch mob as a private citizen but as governor uphold the law. In the same debate, Vardaman promised to purge blacks from the public education system, defended disenfranchisement as a reform vital to the preservation of liberty, and denounced President Teddy Roosevelt for a recent intervention in Mississippi's racial politics ${ }^{12}$. He concluded vowing if elected to "give [the office of Governor] back, unstained, untarnished to the proudest and best people on earth" (New Orleans Daily Picayune July 23, 1903). Reclaiming the state for white supremacy was the cornerstone of Vardaman's campaign (White 1945) and Southern Democratic politics more generally in the period (Foner 1988). While material economic factors have probably contributed to lynching violence, the opportunity structure that shaped it was built through the ideological struggle for the "redemption" of white Southern political power. 
Table 7: Geographic distribution of mob formation events and interventions by category.

\begin{tabular}{|c|c|c|c|}
\hline & Georgia & Mississippi & North Carolina \\
\hline Change in nonlocal involvement & $-7 \%(p=0.988)$ & $4 \%(p=0.190)$ & $26 \%(p=0.000)$ \\
\hline Change in indirect intervention & $5 \%(p=0.121)$ & $11 \%(p=0.033)$ & $7 \%(p=0.207)$ \\
\hline
\end{tabular}

We demonstrate the influence of the Redemption era on lynching through analysis of the three phases that constitute lynching events. In the first phase, mob formation, we find that lynch mobs formed more often in strongholds of Redeemer power: counties heavily dependent on cotton production, with a moderately large black population but dominated in elections utterly by the Democratic Party. Once mobs formed, intervention by state agents was less likely to occur in these same counties until after disenfranchisement. Finally, interventions in general were more likely to succeed following disenfranchisement-primarily because of a shift from risky strategies of direct engagement with mobs to more reliable strategies of indirect intervention, along with an increase in the use of more powerful nonlocal actors to protect mob targets.

Civil wars and their aftermath are transformative events. In addition to martial violence on the front lines, they also generate conditions conducive to "indirect" violence by "ordinary" civilians, creating "irresistible opportunities to harm everyday enemies" (Kalyvas 2006:389). In this article we have argued that the counterrevolution against Reconstruction in the Southern United States provided such opportunities in abundance. Previous scholarship into lynching has looked exclusively at the motivations of individuals to lynch, primarily seeking answers in interracial economic competition (Bailey and Snedker 2011 and Smångs 2016 are notable exceptions). More recent research suggests that political factors are crucial, especially the reaction of the state to the threat of mob violence (Hagen et al. 2013; Kato 2015; Beck et al. 2016). In this article we have attempted to connect "the local and the national, the view from below with the perspective above" (Kalyvas 2006:48). The surge of lynch mob violence in the Southern United States between the end of Reconstruction and the start of the Great Depression can be accounted for, in part, by local whites taking advantage of the instability created by the reconfiguration of the polity to carry out lethal violence against members of a marginalized class-blacks who had been emancipated and incorporated into civic life by force barely a generation before. The lethality of those mobs was shaped by the actions of state actors who at some times and some places encouraged, ignored, or actively opposed such violence. This article shows that only by attending to the determinants of interventions and the drivers of successful interventions can we make sense of the motives that drove white southerners to lynch.

\section{Notes}

1 On the question of the federal government's handling of lynch mob violence, a line of new work by Kato $(2012,2015)$ argues that Federal passivity regarding Southern 
lynching was a result of political calculation rather than legal limitations imposed by Federalism.

2 Note the same process in the contemporary context, through formal legislation designed to inhibit turnout by requiring unusual forms of identification, prohibiting rehabilitated felons from ever voting, and redistricting.

3 The inventory we collected and analyzed in this article is likely to differ from the inventory presented by Beck and coauthors (Beck 2015; Beck et al. 2016) in the following respects: their data are based on a looser definition of "mob threat" for events to be included (i.e., probably contains more events for the three states that the inventories overlap). More specifically, for events in which a journalist made a public statement that he "feared that lynching was imminent" but no mob materialized or no intervention was carried out - even of the most minimal form of posting an additional guard to the jail or making an public appeal by the sheriff to citizens "to remain calm" — we did not include the event, contrary to the decision by Beck and coworkers.

4 Consistent with the literature on lynching, unless the contemporaneous accounts explicitly specify otherwise we assume that the mob's racial composition is white.

5 Not all accounts are so rich with detail. In a number of mob formation events that ended in lynching, the contemporary press reported only that the mob's victims were "taken from custody" and killed. In these detail-poor cases we can discern neither the type of intervention taken nor the extent to which resistance offered by law-enforcement was genuine. These cases could well be instances of what one newspaper called "the Southern precedent of offering a nominal resistance and then yielding to an alleged superior force" (Chicago Daily Tribune June 8, 1901). These equivocal accounts invoke a spectrum of possibilities, from law enforcement collusion with lynch mobs to inadequate reporting on the defeat of state agents. We took a conservative approach to classifying these events for which the press accounts refer to intervention only by reporting that victims were "taken from custody." We coded them as if no intervention had taken place. Given that the boundaries between the different types of actions could be blurry, two independent coders conducted the work. Ambiguous cases were discussed to ensure that the same rules were followed. To further justify this choice, we examined the missing data structure in these articles and compared them to other completed lynching events that saw no law enforcement presence, thus no intervention. Specifically, we tested if newspaper accounts of "taken from custody" cases were any more or less likely to report the following: the settlement or county where the alleged crime the mob target was accused of took place, the nature of this crime, and the size of the mob involved. The logic behind these strategic tests was to rule out that in "taken from custody" cases we lack usual details of the lynching narrative. We found no systematic difference in the missing structure of any of these variables, which strengthens our assessment that the reason why no detailed information was reported on intervention measures is not due to the lack of interest or knowledge of the journalist about the case but rather signals the lack of a legible intervention.

6 Inter-University Consortium for Political and Social Research. Historical, Demographic, Economic, and Social Data: The United States, 1790-1970. ICPSR00003-v1. Ann Arbor, MI: Inter-University Consortium for Political and Social Research. http:/ / www.icpsr.umich.edu/icpsrweb/ICPSR/studies/3.

7 The source of the price and GDP deflator data is the Historical Statistics of the United States Millennial Edition Online, Table Da755-765: Cotton, cottonseed, shorn wool, and tobacco - acreage, production, price, and cotton stocks: 1790-1999. Accessed: 21/02/2014. The cotton prices are averages of state-level prices between 1882 and 1909. From 1910 
onward, we used data at the state level (Cooper 1939). The correlation between statelevel prices and that of the average is very high $(0.999,0.997$, and 0.997 for Georgia, Mississippi, and North Carolina prices, respectively, for the 1910-1930 period). We expect if data were available at a finer resolution before 1910 none of the results presented here would change.

8 We matched candidates to their political parties and coded vote totals as falling into one of four categories: Democrat, Republican, Populist, and Other. Inter-University Consortium for Political and Social Research. United States Historical Election Returns, 1824-1968 [Computer File]. ICPSR00001-v3. Ann Arbor, MI: Inter-University Consortium for Political and Social Research [distributor], 1999-04-26.

9 The functional form we chose reflects the way we theorize this political change to take effect in government and in lay people's hearts and minds. In the online supplement we provide sensitivity analysis to show which aspects of our results would change because of different specifications.

10 The railway data is a courtesy of Professor Nathan Nunn.

11 To capture how embedded communities were in the larger political and economic arena, King and Haveman (2008) use the number of post offices per state as an instrument to estimate the causal effect of print media on the spread of antislavery societies. The reason why this instrument worked well is that post offices were the main channel for distributing newspapers and magazines in the antebellum South. Following a similar strategy, we determined the number of post offices per county using the listings of post offices at the settlement level from 1832 onward from an electronic inventory that we validated by taking a random sample of counties from each state and manually matching the post offices from the digital record to the Record of Appointment of Postmasters, 1832-September 30,1971. We eventually needed to discard this approach because of an administrative change that occurred around 1900-1910 throughout Southern states. In 1896, the federal government began experimenting with the Rural Free Delivery service that aimed to replace the post office system in loosely populated areas with mail carriers who would travel along rural routes delivering mail to residential mailboxes, and by the 1900s the service was formalized and mandated. As a consequence, nationwide the number of post offices peaked in 1901 and has been declining more or less ever since. Establishing these routes was political. Republican congressmen had higher success rates in getting rural routes established than Democratic congressmen. As a consequence, post office counts measure two different concepts before and after the introduction of the Rural Free Delivery system.

12 Vardaman was most likely referring to the "Indianola affair," in which Roosevelt closed a federal post office in Indianola, Mississippi, rather than allow local whites to force the resignation of the black postmaster there. At the time, Roosevelt had taken a more general interest in Mississippi politics, overseeing the reorganization of the state Republican Party. Vardaman seized on the issue of Roosevelt's involvement in the state's racial politics. By the close of the primary campaign, Vardaman was claiming that his election would "mean and be taken to mean by the aspiring, trouble-breeding, ambitious negroes as a condemnation [by] the white people of Mississippi of Roosevelt's policy of social and political equality" (Gatewood 1984:433).

\section{References}

Arellano, Lisa. 2012. Vigilantes and Lynch Mobs: Narratives of Community and Nation. Philadelphia, PA: Temple University Press. 
Bailey, Amy Kate, and Karen A Snedker. 2011. "Practicing What They Preach? Lynching and Religion in the American South, 1890-1929." American Journal of Sociology 117(3): 844-88. http://dx.doi.org/10.1086/661985.

Bailey, Amy Kate, Stewart E. Tolnay, E. M. Beck, and Jennifer. D Laird. 2011. “Targeting Lynch Victims: Social Marginality or Status Transgressions?" American Sociological Review 76 (3): 412-436. http://dx.doi.org/10.1177/0003122411407736.

Brundage, W. Fitzhugh. 1993. Lynching in the New South: Georgia and Virginia, 1880-1930. Urbana: University of Illinois Press.

Du Bois, W.E.B. 1994. The Souls of Black Folk. New York: Dover Publications.

Beck, E. M., Stewart E. Tolnay, and Amy Kate Bailey 2016. “Contested Terrain: The State versus Threatened Lynch Mob Violence." American Journal of Sociology 121 (6): 18561884. http://dx.doi.org/10.1086/685473.

Beck, E. M. 2015. “Judge Lynch Denied: Combating Mob Violence in the American South, 1877-1950." Southern Cultures 21 (2): 117-39. http://dx. doi.org/10.1353/scu. 2015. 0018.

Beck, E. M., James L. Massey, and Stewart E. Tolnay. 1989. "Gallows, the Mob, and the Vote: Lethal Sanctioning of Blacks in North Carolina and Georgia, 1882 to 1930." Law \& Society Review 23 (2): 317-31. http://dx.doi.org/10.2307/3053720.

Beck, E. M., and Stewart E. Tolnay. 1990. "The Killing Fields of the Deep South: The Market for Cotton and the Lynching of Blacks, 1882-1930." American Sociological Review 55 (4): 526-39. http://dx.doi.org/10.2307/2095805.

Blalock, Hubert M. 1967. Toward a Theory of Minority-Group Relations. New York: Wiley.

Campney, Brent M. S. 2013. “'Ever since the Hanging of Oliphant' Lynching and Suppression of Mob Violence in Topeka, Kansas." Great Plains Quarterly 33 (2):71-86.

Cooper, Maurice R. 1939. Statistics on cotton and related data. Washington, DC: United States Department of agriculture.

Creech, James C., Jay Corzine, and Lin Huff-Corzine. 1989. "Theory Testing and Lynching: Another Look at the Power Threat Hypothesis." Social Forces 67(3):626-30. http://dx . doi.org/10.1093/sf/67.3.626.

Eitle, David, Stewart J. D'Allessio, and Lisa Stolzenberg. 2002. "Racial Threat and Social Control: A Test of the Political, Economic, and Threat of Black Crime Hypothesis." Social Forces 81 (2):557-76. http://dx.doi .org/10.1353/sof . 2003.0007.

Ellis, Marie L. 1986. “A Lynching Averted: The Ordeal of John Miller." Georgia Historical Quarterly 70 (2):306-16.

Franzosi, Roberto, Gianluca De Fazio, and Stefania Vicari. 2012. "Ways of Measuring Agency An Application of Quantitative Narrative Analysis to Lynchings in Georgia (1875-1930)." Sociological Methodology 42(1):1-42. http: //dx . doi . org/10.1177/0081175012462370.

Foner, Eric. 1988. Reconstruction: America's Unfinished Revolution, 1863-1877. New York: Harper \& Row.

Gatewood, Willard B. 1984. "A Republican President and Democratic State Politics: Theodore Roosevelt in the Mississippi Primary of 1903." Presidential Studies Quarterly 14:428-436.

Granovetter, Mark. 1978. "Threshold Models for Collective Behavior." American Journal of Sociology 83 (6):1420-43. http://dx.doi.org/10.1086/226707.

Gould, Roger. 2003. Collision of Wills: How Ambiguity About Social Rank Breeds Conflict. Chicago: University of Chicago Press. 
Green, Donald P., Jack Glaser, and Andrew Rich. 1998. "From Lynching to Gay Bashing: The Elusive Connection Between Economic Conditions and Hate Crime" Journal of Personality and Social Psychology 75 (1):82-92. http://psycnet.apa.org/doi/10.1037/ 0022-3514.75.1.82.

Green, Donald P., Laurence H. McFalls, and Jennifer K. Smith. 2001. "Hate Crime: An Emergent Research Agenda." Annual Review of Sociology 27:479-504. http://dx. doi . org/10.1146/annurev.soc.27.1.479.

Griffin, Larry J. 1993. “Narrative, Event-Structure Analysis, and Causal Interpretation in Historical Sociology." American Journal of Sociology 98 (5):1094-1133. http: //dx . doi . org/10.1086/230140.

Griffin, L.J., P. Clark, and J. Sandberg. 1997a. "Narrative and Event: Lynching and Historical Sociology." In Under Sentence of Death: Lynching in the South, edited by W.F. Brundage. Chapel Hill and London: University of North Carolina Press.

Griffin, Larry J., Christopher Caplinger, Kathryn J. Lively, Nancy L. Malcom, Darren McDaniel, and Candice Nelsen. 1997b. "Comparative-Historical Analysis and Scientific Inference: Disfranchisement in the U.S. South As a Test Case." Historical Methods: A Journal of Quantitative and Interdisciplinary History 30 (1):13-27. http: //dx.doi.org/10.1080/01615449709601172.

Hagen, Ryan, Kinga Makovi, and Peter Bearman. 2013. "The Influence of Political Dynamics on Southern Lynch Mob Formation and Lethality." Social Forces 92 (2): 757-87. http: //dx.doi.org/10.1093/sf/sot093.

Holmes, William F. 1970. The White Chief: James Kimble Vardaman. Baton Rouge: Louisiana State University Press.

Kalyvas, Stathis. 2006. The Logic of Violence in Civil War. Cambridge: Cambridge University Press. http://dx.doi.org/10.1017/CB09780511818462

Kato, Daniel. 2012. "Strengthening the Weak State: Politicizing the American State's 'weakness' on Racial Violence." Du Bois Review 9:457-480. http://dx.doi.org/10.1093/ acprof : oso/9780190232573.003.0002.

Kato, Daniel. 2015. Liberalizing Lynching: Building a New Racialized State. Oxford University Press. http://dx.doi.org/10.1093/acprof : oso/9780190232573.001.0001

Key, Vladimir O. 1949. Southern Politics in State and Nation. New York: A. A. Knopf.

King, Marissa D., and Heather A. Haveman. 2008. “Antislavery in America: The Press, the Pulpit, and the Rise of Antislavery Societies." Administrative Science Quarterly 53 (3): 492-528. http://dx.doi.org/10.2189/asqu.53.3.492.

Kousser, J Morgan. 1974. The Shaping of Southern Politics: Suffrage Restriction and the Establishment of the One-Party South, 1880-1910. New Haven, CT: Yale University Press.

Krueger, Alan B., and Jorn-Steffen Pischke. 1997. "A Statistical Analysis of Crime against Foreigners in Unified Germany." Journal of Human Resources 32(1):182-209. http: //dx.doi.org/10.2307/146245.

O'Connell, Heather A. 2012. "The Impact of Slavery on Racial Inequality in Poverty in the Contemporary U.S. South." Social Forces 90 (3):713-34. http://dx.doi .org/10.1093/ sf/sor021.

Olzak, Susan. 1990. "The Political Context of Competition: Lynching and Urban Racial Violence, 1882-1914." Social Forces 69 (2):395-421. http://dx. doi .org/10.1093/sf/69. 2.395.

Perman, Michael. 2001. Struggle for Mastery: Disenfranchisement in the South, 1888-1908. Chapel Hill: University of North Carolina Press. 
Raper, Arthur Franklin. 1933. The Tragedy of Lynching. Chapel Hill: University of North Carolina Press.

Reed, John S. 1972. "Percent Black and Lynching: A Test of Blalock's Theory." Social Forces 50 (3):356-60. http://dx.doi.org/10.1093/sf/50.3.356.

Smångs, M., 2016, “Doing Violence, Making Race: Southern Lynching and White Racial Group Formation." American Journal of Sociology 121 (5):1329-74. http://dx . doi .org/ $10.1086 / 684438$.

Snyder, David, and Charles Tilly. 1972. "Hardship and Collective Violence in France, 1830 to 1960." American Sociological Review 37 (5):520-32. http://dx.doi .org/10.2307/ 2093448.

Soule, Sarah A. 1992. "Populism and Black Lynching in Georgia, 1890-1900." Social Forces 71 (2):431-49. http: //dx.doi.org/10.2307/2580018.

Stovel, Katherine. 2001. "Local Sequential Patterns: The Structure of Lynching in the Deep South, 1882-1930." Social Forces 79 (3): 843-80. http://dx.doi.org/10.1353/sof . 2001. 0026.

Tolnay, Stewart E., and E. M. Beck. 1995a. A Festival of Violence: An Analysis of Southern Lynchings, 1882-1930. Urbana and Chicago: University of Illinois Press.

Tolnay, Stewart E., and E. M. Beck. 1995b. "Racial Violence and Black Migration in the American South, 1910 to 1930." American Sociological Review 57(1):103-16. http: //dx.doi.org/10.2307/2096147.

Tolnay, Stewart E., Glenn Deane, and E. M. Beck. 1996. “Vicarious Violence: Spatial Effects on Southern Lynchings, 1890-1919." American Journal of Sociology 102 (3):788-815. http://dx.doi.org/10.1086/230997.

Wilson, William Julius. 1980. The Declining Significance of Race. Chicago: University of Chicago Press.

White, Eugene E. 1945. “Anti-Racial Agitation As a Campaign Device: James K. Vardaman in the Mississippi Gubernatorial Campaign of 1903." Southern Speech Journal 10:49-56. http://dx.doi.org/10.1080/10417944509370928.

Acknowledgements: The authors thank Nathan Nunn, Eric Foner, Karen Barkey, Charles Seguin, Christopher Muller, members of the Organizations Workshop at the University of Chicago, and the XS workshop at Columbia University for their helpful comments.

Kinga Makovi: Department of Sociology, Columbia University.

E-mail: km2730@columbia.edu.

Ryan Hagen: Department of Sociology, Columbia University.

E-mail: rah2168@columbia.edu.

Peter Bearman: INCITE, Columbia University. E-mail: psb17@columbia.edu. 